\title{
Children's Rights in an Age of Information and Communication Technologies
}

\author{
María Rosa Buxarrais and Miquel Martínez
}

University of Barcelona, Spain

\begin{abstract}
We live in a socio-cultural, informational and technological context that poses new educational challenges for society in general but above all for children. In this paper, we present a proposal that should help to maximise the capacity of children to face the challenges presented by today's society. We draw attention to the fact that in an age of information technology such as ours, children as a group risk marginalization. The children's bill of rights in the XXI century needs to build on those drawn up in the XX century and should be extended to include those rights that safeguard life styles and living conditions and a child's right to play and learn, in keeping with the specific conditions of the XXI century. To this end, we frame a proposal concerning the rights of children in a society increasingly dominated by information and communication technologies. Throughout Europe, there is much current debate about children's rights linked with mass media and information and communication technologies. We describe several projects that offer hope for the promotion of greater responsibility on the part of the mass media given their pervasive ability to shape thinking, projects that may help to mitigate the influence of the media, including information and communication technologies on children.
\end{abstract}

Key words: children's rights, children, society of information and technologies, mass media, information and communication technologies, values education.

\section{RESUMEN}

Vivimos en un contexto sociocultural, informativo y tecnológico que plantea nuevos retos educativos para la ciudadanía en general y, en particular, para la infancia. Defendemos una propuesta formativa que debe contribuir a potenciar al máximo las capacidades de la infancia para afrontar los desafíos que la nueva sociedad le presenta. Alertamos de que un tipo de sociedad como la nuestra genera nuevos excluidos y nuevos vulnerables que pueden convertirse en futuros excluídos en función de las condiciones de vida, aprendizaje y educación que rodeen a la infancia. La carta de los derechos de la infancia en el siglo XXI debe continuar insistiendo en los formulados en el siglo XX y debe completarse con aquellos que sean garantía de estilos y condiciones de vida, juego y aprendizaje adecuados en el siglo XXI. Por lo tanto, realizamos una propuesta sobre los derechos de la infancia en la sociedad de la información y las tecnologías. Actualmente en Europa emergen nuevos debates sobre valores relacionados con la aplicación de los derechos de la infancia en los medios de comunicación y en las tecnologías de la información y la comunicación. Así pues, presentamos algunas iniciativas en las que hemos participado, que desde nuestro punto de vista son significativas porque fomentan unos medios de comunicación más responsables, tienen en cuenta 
su capacidad moldeadora y contribuyen a paliar los efectos de los medios y la influencia del uso de las tecnologías de la información y la comunicación por parte de la infancia.

Descriptores: derechos de la infancia, infancia, sociedad de la información y las tecnologías, medios de comunicación, tecnologías de la información y la comunicación, educación en valores.

RÉSUMÉ

Nous vivons dans un contexte socio-culturel, informationnel et technologique qui pose de nouveaux défis éducatifs pour la société en général mais surtout pour les enfants. Dans ce papier, nous présentons une proposition qui devrait aider à maximiser la capacité des enfants de faire face aux défis que présentent la société d'aujourd'hui. Nous attirons l'attention sur le fait qu'en cet âge de l'informatique tel que le nôtre, les enfants, comme groupe, risquent d'être maginalisés. La déclaration des droits des enfants au XXIe siècle doit ajoûter à celles qui ont été dressées au XXe siècle et devrait s'étendre afin d' inclure les droits protégeant les styles et les conditions de vie ainsi que le droit des enfants de jouer et d'apprendre, en accord avec les conditions propres au XXIe siècle. À cette fin, nous élaborons une proposition concernant les droits des enfants dans une société de plus en plus dominée par les technologies d'information et de communication. Partout en Europe, il y a actuellement beaucoup de débats au sujet des droits des enfants en lien avec les mass-media et les technologies d'information et de communication. Nous décrivons plusieurs projets qui offrent de l'espoir pour la promotion d'une plus grande responsabilité de la part des mass-média, étant donné leur insidieuse habileté à former la pensée, des projets qui pourront aider à mitiger l'influence des média, incluant les technologies d'information et de communication, sur les enfants.

Mots-cléfs: les droits des enfants, les enfants, une société d'information et de technologies, les massmedia, les technologies d'information et de communication, éducation aux valeurs

\section{The First Generation of the Rights of the Child and the Life Styles of Contemporary Society}

$\mathrm{C}$ HILDREN AND ADOLESCENTS in Europe in the XXI century are growing up in quite different family and educational environments from those in the last quarter of the XX century. Our knowledge of these contexts and the way in which they affect personal growth and the processes of development and learning of this generation are inadequate. The notion of social exclusion has changed and is related among other factors to the way in which the person, adolescent or young adult is initiated into the social life of work or study and of leisure, the group and the wider community. The individual's acquisition of skills helps in her ethical-cognitive development and determines just how vulnerable she will be in the contexts afforded by the pluralist information age in which we live.

Learning to learn, to understand, to act and to live in this world and learning to live with others require high levels of functional, emotional and ethical literacy. They require us to forge a conception of ourselves that generates confidence in our ability to construct our personal identity through social interaction. This process of human development occurs in the very heart of the affective, emotional, social and informational environment in which childhood and adolescence are lived. The worlds of the family and the school have traditionally provided this developmental context.

In recent decades, however, a variety of perspectives drawn from theories of social learning and social development, non-formal and informal education, social communication, particularly that of television, and from the new technologies have influenced 
the contexts of child rearing and children's personal development. Despite this, however, we have retained an abiding and sometimes excessive confidence in the role of the family as the primary source of informal education and in the role of the school for overcoming any disadvantages.

The changes generated by the impact of information and communication technologies are, moreover, causing a fundamental shift in the role of the family and the school as contexts of socialization. In addition, the changes related to job insecurity, the increase in immigrants coming to the countries of Western Europe, and the changes in family structure that undermine the stability and resilience of conjugal and parental relations produce new risks and difficulties in developing inter-generational social links. The repercussions of these changes can also affect the personal and social development of the child making her more vulnerable to the processes of social exclusion.

If public policies fail to include programmes aimed at preventing social exclusion directed specifically at the home and family, the information and technological society facing us will not be a society of knowledge or continuous and autonomous learning for all. The absence of such public policies will have a direct impact on the development of the capacity for social integration of the youngest people in the group, namely, children. The challenge of achieving effective social integration and avoiding social exclusion will still rest with the family as a living space and as the primary context for the nurturance and education of new generations. In this context, we believe that the human rights charter for children in the XXI century must continue to build on those drawn up in the XX century and must incorporate those rights that will guarantee life styles and living conditions, as well as the rights to play and to learn, appropriate for the XXI century.

\section{The Information Society and Education}

The paradox of the twenty-first century is that, on one hand, it is witnessing the consolidation of longstanding injustices, while on the other it is signing declarations of good intentions, proclaiming rights for all and drafting international protocols and commitments for a fairer, more dignified world. This paradox lies at the very heart of our world, and in particular of the most developed regions.

This paper proceeds from the belief that this situation will not be easy to change but also from the conviction that change is possible. Our argument and proposals rest on the recognition that the socio-cultural, informational and technological context in which we live sets new challenges for us all, but especially for our children. These challenges are perhaps most complex in those parts of the world already engaged in the revolution created by information and communication technologies, but where the social context does not yet represent a society committed to knowledge, learning or communication for all.

Children are not just important as persons in their own right. They are also critically important as the actors who will help build a fairer, more dignified world. The lives led by boys and girls today will strongly influence their behaviour as the adults of the future. Their education - be it formal, non-formal or informal - that influences and 
perhaps even determines their development as adults, therefore takes on the value of a positive externality, not only justifying the investment in education as the formation of human capital, but also, that of social capital.

Our world is undergoing a set of qualitative changes that are forcing us to reconsider the basic skills necessary to enable us to understand these changes and to develop as individuals. Globalisation and the information revolution have brought about changes in our way of life and in our understanding of the world and our place in it. Consequently, education faces new challenges, and the measures we adopt affecting children need to satisfy new educational and learning needs. Indeed, these needs now have to be added to the biological, social, affective and legal needs characterizing the children's bill of rights to date, so that such charters are more complete and representative of current imperatives.

Various authors ${ }^{1}$ have described our world as constituting a new model of society since we are witnessing changes that simultaneously affect relations of production, power and life experience. These changes suggest a series of thoughts and ideas with pedagogical implications. Consideration of these implications is necessary to provide a better description of the range of settings requiring the acquisition of competence if we wish to transform the information that surrounds us into knowledge, learn how to interact effectively in today's technological world and, in short, learn how to live and work critically and actively in plural societies. Such considerations should be incorporated as criteria that might guide measures adopted in children's education, inasmuch as children form part of society, are entitled to the protection of bills of rights and expected to acquire civic understanding so they can discharge their duties as responsible citizens of the state.

We are convinced that the skills necessary to achieve competence are acquired through practice and use, and that they are not skills to be learned for the future but skills that are integral to the very processes of growth and development. Such skills are not merely declarations of good will or the final objectives on the curriculum. They are skills that become consolidated and learned when they form part of the personal and social contexts of children as they grow and develop.

We have already mentioned the qualitative changes that are occurring in the relations of production, power and personal experience. In production, greater emphasis is increasingly being given to the marked differentiation between two types of worker: those who are able to learn in order to learn, take decisions autonomously and adapt to change, and those who undertake tasks automatically showing little or no initiative. The former are not only those who find work more easily, but they are also those who remain employed longer and the ones who derive greater personal satisfaction from their work. The latter are people who are easily replaced despite the importance of the tasks they perform. Under such circumstances it is difficult for such workers to derive much personal satisfaction from their work. Against this backdrop, education and the learning processes involved in it should not, we contend, be seen as a simple process of receiving orders, information and stimuli to which the child offers elementary responses or emits simple signals in a linear and simplistic manner. Education understood in this way, i.e. overly mimetic and encyclopaedic, without the requirement to 
provide meaningful knowledge and information, will generate, in the best of cases, persons who will derive little or no satisfaction from their work.

We contend - pedagogical niceties aside - that from the perspective of the job market, education should seek to maximise a child's capabilities for learning. Such a perspective implies that young people should learn how to use and manipulate information, how to select, organise, and to give information meaning. At the same time the child should be taught how to express herself as richly and as fully as possible, how to take decisions and to identify personal criteria and priorities in organising her work, how to work as a member of a team, to be enterprising, to take the initiative and how to handle change easily and adapt to new situations in a singular and meaningful way. For this reason, children need to develop the capacity of autonomy, self-confidence in their own possibilities and self-assurance.

The changes affecting power relations are increasing disparities both between different areas of the world and between different sectors of the population within the same country. The information and technology society has contributed to the fact that political, economic and cultural power is increasingly concentrated in the hands of those who are technologically most powerful, thereby exacerbating inequality and social polarisation and generating areas and populations of social exclusion.

Developments in science and technology, the processes of globalisation, migratory movements and the deterioration of the welfare state make up the stage on which the degree "of manufactured uncertainty" of which Giddens ${ }^{2}$ talks. This uncertainty is becoming an increasingly decisive factor in the formulation of proposals for education that will enable people to take the initiative in their decision-making and, at the same time, ensure they are the author and master of these decisions. For this to occur, we need to educate children to respect difference, to become involved in collective proposals that seek the common good rather than satisfy their personal interests. In short, and notwithstanding situations that involve minor disappointments, children need to learn that the search for progressive degrees of equality, justice and solidarity do not always lead to the material betterment of the individual but rather just the opposite in the case of those who are better off. Environmental conservation, the preservation of our cultural heterogeneity, the promotion of our own culture and identity, being selfcritical of our culture and accepting the other on equal terms when deciding on collective issues, all require us to learn, but in particular our children, a set of skills that cannot be improvised and which should be present in our proposals for education, because they are and will become more necessary for advancement in plural societies such as ours.

Up to this point we have stressed the needs derived from the world of work and production, and those derived from the crises and weaknesses suffered by the democratic systems in which decision-making is not always entirely ethical, albeit the will of the majority. But this new model of society in which we live is also defined by changes in our life experiences. These changes and the absence of fixed reference points and absolute values as a model for the younger generations to imitate, leave our children in situations of much greater vulnerability than in the past. Before, young people adopted the models of behaviour learned from their elders. Over the last few decades, relation- 
ships and personal experiences have become self constructed patterns, and for this to happen individuals have to be trained. Today it is more necessary than ever before to take charge of the process and to demonstrate and develop attitudes that favour an autonomous construction of the self in our own lives. Those who are unable to construct a strong sense of self through their relationships and real experiences will be subject to the homogenising pressure of the mass media and social leaders.

We need to ensure that our children are taught how to use technological advances autonomously, critically and efficiently in the context of guaranteed Internet access. But this is just one part of the question. A second aspect, more global and far-reaching, is that we should also prepare them to live in a technological society which increases their vulnerability and extends this defencelessness to sectors of children not previously considered at risk.

The new possibilities provided by interpersonal communication can have beneficial effects for those who control them but a negative impact for those subjected to their effects or for those excluded from their use because they lack requisite skills. This highlights the need for a technological and communicative literacy that permits the use and control of this communicative sphere by children. The exclusion resulting from the control of technological and communicative literacy evident in certain geographical regions, but also within our society at large through the generation of new categories of access and optimum use, is a real threat to the democratic nature of our society.

Participating in collective decision-making and being able to control those decisions that are adopted implicitly in the development of this sphere of communication should lead to our reconsidering the ways in which education and the schools, in particular, might ensure that the school population is prepared for incorporation into adult society and to our examining the democratic means that over the last century have come to shape our social and political contexts.

The leading media groups wield a homogenising power that knows no physical or cultural boundaries. The structure of their messages, the learning of life styles, fashions, customs and ways of understanding and living in the world generate patterns of life in which socialisation is developed principally through consumerism and in which our ways of living are increasingly the fruit of imitation and reproduction of models and which, as a consequence, lose their individual distinctiveness. Consequently, and despite the fact that the way we live is not the exclusive determinant of who we are, the pervasive influence of media weakens the capacity of individuals to define for themselves a strong senses of self and creative identity.

Education, and once again schools in particular, in their awareness of these environmental conditions arising from technological development, need to focus more strongly on educational practices that can mediate between the media and children and help the latter integrate the information, cognitive strategies and attitudes offered by the media in a meaningful and critical way. This task is not exclusively that of the schools, but should also be the responsibility of those families in a position to carry it out. To accomplish this, however, requires a better understanding on the part of teachers and parents alike of the media and the products designed for children and adolescents. 


\section{Towards a New Conception of Social Exclusion: Children and Their Social Vulnerability}

Social exclusion may be considered to have grown out of the crisis suffered by the welfare state. The neo-liberal movement was born as an expression of opposition to the egalitarian tendencies adopted earlier in the idea of the welfare state. In neo-liberal eyes, the welfare state acts as a brake on economic growth, hence the need to dismantle it. $^{3}$ Once dismantled, any social policy becomes meaningless, which in turn leads to growing social inequalities. Consequent social vulnerability runs the risk of developing into a radical form of exclusion. Ramon Cotarelo argues that in democratic systems it is not easy to weaken the welfare state, however, the stagnation that it suffers results in an increase in the demands of the beneficiaries for social welfare to help those who are comparatively worse off and to reintegrate those who have become socially excluded or marginalised. ${ }^{4}$ When this increase occurs and the state cannot respond adequately, a population is created that is susceptible to being managed. It is at this point that exclusion becomes a matter of public policy since it includes a cognitive dimension - rendering social matters problematic, and a policy dimension in which actions are undertaken - the responses to these social issues. ${ }^{5}$

In recent years neither economic growth nor the development of the social services has reduced the evidence of marginalization and social exclusion. What is more, the gap between the life styles and opportunities available to the richest and the poorest sections of society has not become smaller. To the contrary, we have witnessed an increase in unemployment and poorly paid temporary work where hopes of self-improvement are few and far between. Thus, the difficulties of integration and the risks brought by a lack of job security have had a marked effect on certain sectors of society, while, at the same time, this sensation of insecurity and vulnerability has grown throughout the whole of society ${ }^{6}$. Seen from this point of view, exclusion is shifting towards the more central sectors of society bringing with it a modification in its very structure, hence today what is important is not so much a hierarchical position but one of centrality.

The concept of exclusion became detached from that of poverty at the beginning of the nineties with the designation of a new way of approaching the social question. The changes brought about at a structural level shifted the debate towards the concept of exclusion, which is seen to include poverty but extends further to recognise also the difficulties for personal growth, for forming part of the community and for accessing the previously established systems of protection. ${ }^{7}$ Most authors agree that exclusion is a social structural phenomenon as far as social inequalities throughout history are concerned; dynamic, insofar as it is constantly changing in terms of the individuals and social groups it affects; multi-factorial, due to the concurrence of unfavourable and interconnected circumstances; and a political issue that can be tackled with public and social policies. ${ }^{8}$

The pervasive presence and reach of information and communication technologies sets each of us new challenges both as individuals and as successful members of the community. The concept of social exclusion and above all that of growing social vulnerability are changing the classic content of these terms. Society today is producing 
new victims of social exclusion and, in particular, children who are increasingly vulnerable to being excluded because of the conditions of life, training and education that they face. Together with the classic meanings attributed to exclusion in structural terms, many of which are undoubtedly well-founded, we need to consider those related to the cognitive and ethical profile of the subject.

Belonging to sectors traditionally considered in structural terms as being "nonexcluded sectors," or belonging to those classes with a certain economic standing, with full employment and with a medium to high cultural level, is no guarantee that the individual will escape exclusion. The children of these families are also not exempt from exclusion. Vulnerability leads to the destabilisation of the stable and to their immersion in a precarious state. ${ }^{9}$ Vulnerability also affects those who are socially integrated and those who have a job. As we have suggested, the new modes of production require workers of a new profile, and they no longer have the guarantee of protection and security until this point in time provided by the social system of the welfare state. Rather, they require workers with personal profiles able to overcome adverse or unstable conditions in their working lives.

This growth in vulnerability not only affects those already integrated, but also those who have yet to set out on the road to social and professional integration. It affects, for example, young people looking for their first job or those wishing to undertake their first post-compulsory studies. In the same way that we might differentiate within our analysis of social exclusion a set of interpretations centred on social exclusion as an attribute of the person from those attributes centred on social exclusion as a property of societies, ${ }^{10}$ we believe that it is possible to see vulnerability as an attribute of the individual and also of the spaces and settings for development and education which foster or limit the optimisation of the person.

Vulnerability can lead to disaffiliation ${ }^{11}$ which is characterised by the failure to participate in the productive life and by the absence of social relations. As Anna Jollonch points out when quoting Castel, disaffiliation is the effect of the conjunction of two vectors: that of integration - the failure to integrate in the workplace, and that of insertion - the failure to become inserted socially. In today's society, integration in the productive relations and social insertion require a set of skills, primarily practical, which have nothing in common with a set of simply informational and conceptual skills or with an encyclopaedic conception of knowledge. They are skills related to procedural, attitudinal and ethical forms of knowledge. They are skills attained by developing competencies that require a reassessment of education and lifelong learning, particularly the schooling of children.

They include, among others, skills such as: learning to learn in an autonomous and on-going manner; adapting to change; constructing knowledge by giving meaning to the information that surrounds us in the context afforded by today's technology; demonstrating a pro-active and enterprising attitude, as well as an interest and commitment to collective undertakings; possessing the skills and resources needed to ensure a good level of mutual coexistence in different societies; being trained in the construction of one's own personal identity; being able to ponder socio-moral questions and to 
participate in the taking of decisions that affect not only our personal interests but also those of the group as a whole.

The child with a poor control over those abilities, thereby preventing her from mastering the skills listed above, finds herself potentially vulnerable even though neither she nor her family belongs to traditionally excluded sectors. This does not mean, however, that having high levels in the aforementioned skills is any guarantee that the individual is not at risk. There are other factors, in addition to those of an ethical and cognitive nature, that play a role and which can lead to vulnerability or exclusion regardless of the ethical-cognitive profile of the subject in question.

Together with the effects of job insecurity, and the weaknesses of the networks of relations present in our society, pedagogical and social spaces and settings exist that can contribute to the development of individual capabilities such as those listed here, or equally which might heighten the effects of insecurity and social fragility. Family life styles, interpersonal relations and the models of harmonious living which are learned and consolidated in the games and in the settings of a child's formal and informal education are factors that can facilitate or impede the acquisition of these skills and which might lead to situations of vulnerability and future disaffiliation.

\section{Measures for Protecting Children's Rights in Relation to Screen Technologies}

We are now truly immersed in the so-called "information society" and as a result the telematic media have become increasingly present in our daily activities, while the rate of development of these technologies continues unabated. For this reason, most political debates today within the European Union identify the need for urgent action and specific solutions to all the problems that are emerging in relation to the new technologies. ${ }^{12}$

Undoubtedly, one of the main challenges facing professional educators is the need to understand the relationship between children andInformation and Communication Technologies, the so-called "screen technologies". ${ }^{13}$ These technologies are widening the horizons of communication, generating "new" cultures and facilitating the development of new skills and new ways of building knowledge ${ }^{14}$. As a result, new questions are being asked concerning the direction we wish society to move in. In Europe we are seeing the emergence of new debates about our values and some of these discussions are concerned with the way in which children's rights ${ }^{15}$ need to be respected in the media and when using information and communication technologies (ICTs).

What is the relationship between children's values and their use of these technologies? Undoubtedly the latter have more impact than we imagine because they are pervasively present. It is also necessary to examine whether and how these technologies are influencing the content of communication between parents and their children, because we are increasingly noticing that the cause of non-communication in families seems to lie in the parental lack of understanding of these technologies. The present generation were born with the ICTs unlike their parents' generation. For children today these technologies are just one more element in their daily lives. 
This is the first generation actually born into the information society and who, in their patterns of consumption and cultural behaviour, represent a break with the habits and behaviour of their parents and grandparents. They are subjects who live in an urban environment, consume all types of media products, invest a large part of their leisure time in using various types of technology (television, video, games, computers, mobile phones, etc.), they are put into schools during the first few months or years of their lives, they socialise in very small family environments, they have a very direct relationship with the adult world, they are over-stimulated or saturated with information and cultural and media experiences, they develop habits and behaviours of a high level of consumerism, among various other notable features. ${ }^{16}$

It might be thought that the protection of, and attention for, children is obvious and natural - an inalienable and unquestionable right, but this is not always the case ${ }^{17}$ (Mon and Muriel, 1994). The development of technologies has resulted in the development of an area of analysis and research to determine the extent to which these technologies impact upon and form part of the daily lives of children. Studies have been undertaken into how boys and girls use these technologies, how much time they spend with them, etc. (Clearinghouse on Children and Violence, 2000). By contrast, less research has been conducted into how these experiences and the children's understanding of $\mathrm{ICTs}^{18}$ are manifest and are identifiable in the dialogues they maintain with each other and with their parents. ${ }^{19}$

Undoubtedly, the relationship between children and screen technologies has acquired many facets and features. The screen technologies on the one hand can protect, inform, educate, nurture and entertain the children in a unique and varied way, and yet, at the same time, they have the power to exploit, abuse, misinform and exclude. Educational software programs are being designed and training plans drawn up for teachers in the fields of communication and New Technologies. ${ }^{20}$ To analyse the type of actions and developments undertaken in relation to the application of the Convention on the Rights of the Child in the area of screen technologies, we distinguish between two areas: the Media of Mass Communication ${ }^{21}$ and ICTs.

\section{Children and the Media of Mass Communication}

Recent years have witnessed a number of major initiatives undertaken to promote greater responsibility in the mass media and to reflect the opinions and the situation of children more accurately. For example, materials have been used in an attempt to promote the development of a fairer, more protective society - a society where everyone, but especially children and women, enjoy a position of equality - in seminars with the mass media held in Albania, India, Kenya, Malawi, Mozambique, Nepal, Romania, Sri Lanka, East Asia and the Southern Pacific. In 1996, the International Save the Children Alliance presented a number of ideas to the "Committee for Children's Rights" in order to implement a series of directives concerning children's rights for journalists, advertising firms, NGOs and other organisations and individuals concerned with children's issues. A defender of children's rights from Norway directed the Oslo Challenge Project in 1999. This project placed great emphasis on working with professionals 
from the media in the preparation of Guidelines for the Media and Children, following an exhaustive analysis of the international mass media and questions concerning children's rights. ${ }^{22}$

Another fundamental aspect in these projects was the attempt to ensure that the opinions of the children themselves were taken into consideration in producing the contents of the mass media. For example, the projects ensured that boys and girls participated in the process of producing realistic and positive images of children in the broadcasting media. To achieve this, children needed to have greater opportunities for producing their own materials for use in the media. Every year, UNICEF patronises the International Children's Day of Broadcasting, an opportunity to present the courage, creativity and energy of children in the audio-visual media. ${ }^{23}$

The Convention on the Rights of the Child, agreed to in its first draft by the UN in 1959 and developed more fully on 20 November 1989, sets itself the main aim of ensuring that all minors enjoy a happy childhood and can enjoy, for their own good and that of society as a whole, the rights and freedoms contained therein. Similarly, it urges fathers and mothers, organisations, local authorities and national governments to recognise these rights and to fight for their implementation by the talking of legislative measures. In particular, the Convention dedicates two articles (13 and 17) to children's communicative rights and those related to the media dedicated to children. These articles clearly lay down what they consider to be suitable contents for children and young people in general: contents which are oriented at developing their capabilities, faculties and mental and physical maturity, contents which respect their cultural identity, contents which promote citizenship in keeping with their human rights, freedom, tolerance and contents which contribute to encouraging respect for the environment. The need is also established to protect children from any information or material that might be prejudicial to their well-being. ${ }^{24}$ The public powers in their legislative role should stimulate such contents in the mass media and should create directives in order to protect minors.

In October 1989, the European Commission, the European Parliament and the Council of Europe adopted the Television without Frontiers Directive. This directive has two objectives: 1) to create a common market for the dissemination of television upholding cultural differences, protecting consumers and minors and providing the right of reply, 2) to promote the distribution and production of European audio-visual programmes, and to guarantee them a place in the schedules of the European television networks.

This law prohibits the broadcasting of programmes that might be prejudicial to the development of minors both in terms of the programmes themselves and advertising.

Article 17, section 2 states:

"Programmes that are likely to be prejudicial to the physical, mental or moral development of minors and, in particular, those that contain scenes of pornography or gratuitous violence can only be broadcast between $10 \mathrm{pm}$ and 6 am and warnings concerning their content should be made using either acoustic or optical means.” 
The results of the application of the Television without Frontiers Directive have been such that between 1984 and 1994 no legal proceedings had to be brought, despite the frequent number of infractions. Between 1994 and 1996 proceedings were only brought twice and between 1996 and 1997 on just four occasions, and in all cases in relation to the advertising of alcoholic drinks, not to programme contents. The directive is currently being revised. The production quotas, the protection of children and the regulation of advertising are the central themes in the debate. Once finished the revision will complete the second modification of the Television without Frontiers Directive.

A number of similar local initiatives have occurred. For example, in Catalonia, on 4 December 2001, and on the initiative of the Catalan Audio-visual Council ${ }^{25}$ a forum for audio-visual users was set up ${ }^{26}$ with the aim of establishing a framework for exchanging information and ideas, and to provide a response to the demands of the civil society in this sector. The Forum comprises entities, associations, organisms, universities, trade unions and professional institutes, interested in the world of the users of audio-visual media. It is organised in working groups so that specific issues can be examined in detail and documents prepared to promote the quality of programming and the good use of the media.

The working groups currently engaged in tasks related to the audio-visual media are: 1) the Children and Adolescent group, 2) the users group, 3) the group concerned with diversity, 4) the training group. The studies published to date by these groups include: the rights of the users of audio-visual media, ${ }^{27}$ the values reflected in television programmes for children and young people ${ }^{28}$ and the diptych Recommendations: Family and Values. ${ }^{29}$

Television is one of the mass media of communication that explicitly or implicitly transmits certain values. It is important that the values transmitted by both public and private television companies do not differ from or contradict universal values (justice, freedom, solidarity, respect of differences, equality, life, peace, etc.) To ensure this we believe that programmes for children and young people should respect the values contained in the Universal Declaration of Human Rights and in the Spanish Constitution. We also believe it necessary that they have as their frame of reference, the values established in a number of different regulations - Law 1/3 October 1990, concerning the general planning of the educational system, Law 8/27 July 1995, concerning the protection of children and adolescents, Law 25/12 July 1994, modified by Law 22/7 June 1999, concerning television without frontiers - and the various codes of self-regulation implemented by the television channels themselves.

Television programmes are frequently criticised for their poor quality and absence of ethics, but the extent to which they educate or corrupt, in other words, the extent to which they transmit positive or negative values is not always taken into consideration. Television messages usually adopt specific narrative forms (serials, news stories, advertisements among others). To verify what positive and negative values are transmitted in these messages, it is necessary to observe not only the verbal but also the non-verbal codes used in their configuration. What really makes an impact on television viewers, above all on children and adolescents, are not just the words but also the narrative 
structure, the configuration of the images, the selection of camera positions and points of view, the rhythm, the sounds and the music. The combination of all these elements transmits positive and negative values and tends to create and strengthen certain stereotypes among viewers.

We should highlight the need to include the teaching of audio-visual language in the framework of formal and non-formal education. Education cannot afford to ignore this medium when the average child spends three hours each day sitting in front of television. Educating television viewers, however, involves more than protecting children from the audio-visual media. The actions undertaken in the field of children's education, the training of teachers and raising the awareness of the rest of the educational community (family and other institutions) can help guarantee that audio-visual media are used with the knowledge needed to ensure the application of a critical sense. We cannot afford to ignore either the school or television because they both contribute to forging the vision the younger generations have of the world.

For these reasons, all those involved in the production, direction and watching of children's programmes, as well as the educational community in general, need to keep a careful watch on its expository and interpretative quality and ensure that the contents of this type of programming are coherent with the values discussed in this paper. In this context, we believe that it is essential that media professionals be made aware of the importance of children's rights.

a Ethical questions should form a part of a journalist's training, especially as regards the code to be adhered to when reporting the problems that children face. Documents such as the "Convention on the Rights of the Child" and its implications for the mass media, as well as examples of best practice within the mass media, should serve as the basis for organising training courses and preparing manuals for journalists and other media professionals.

b Governments and politicians should work more closely with the mass media and other groups in creating a legal and cultural framework for journalism, especially through the introduction of legislation regulating the freedom of information and an independent press.

c Media professionals accept that freedom of expression should go hand in hand with other basic human rights, including the right to freedom from all forms of exploitation and intimidation. In their evaluation of the merits of individual cases, they should weigh up carefully the facts and not allow themselves to be governed by purely commercial or political considerations.

d A dialogue between the media companies, journalists and the producers of television programmes, on the one hand, and various sectors of society, on the other, should be engaged to highlight problems and concerns and achieve a better understanding of the needs of journalists and the media as regards their reporting stories about minors.

e The national NGOs should examine the possibility of drawing up a list of reliable experts on matters concerning children's rights and related issues for distribution in the media. This information could also be accessible via a computerised database. 
f Journalists and TV producers should be responsible for raising public awareness on matters regarding the violation of children's rights. Such reports need, however, to be produced with great care. In particular, the media should adhere to the strictest code of ethics when reporting issues related to children's rights. They should avoid and combat the building up of myths and stereotypes around children, in particular in developing countries. $^{30}$

g Public and private suppliers need to be regulated to guarantee a wider offer of material, specifically that designed for children and for boys and girls of all ages.

\section{Children and ICTs}

The present-day characteristics of the Internet, specifically the great freedom of expression it enjoys and the enormous challenge it presents in regulating the distribution of its contents, are a matter of grave concern for many sectors of society, primarily because of the influence they can have over children. Fraudulent activities, pornography, pederasty and hackers proliferate. In such an environment, children, by definition, are without protection and are extremely vulnerable. For this reason, it is the duty of us all to protect them against materials that might threaten their growth and development as social beings.

This concern has seen democratic governments seek ways to protect children from the Internet. Laws have been passed to regulate access to inappropriate contents, to guarantee the privacy of information, and technology has been developed to filter out those contents considered prejudicial to children. The European Commission is developing a plan of action for a safer Internet by working in three main areas: the creation of a safe environment for minors, basically by setting up a network of "direct lines" and promoting self-regulation and codes of practice; the development of filter systems and the classification of contents, and the preparation of awareness raising activities. ${ }^{31}$ Despite the risks that the Internet represents for children, it has the potential to become one of the most democratic and participatory structures that the ICTs have introduced to a world that is celebrating the fiftieth anniversary of the Universal Declaration of Human Rights. Recently UNICEF has presented a "Decalogue of children's rights and duties on the Internet", called the Decalogue of e-rights for boys and girls. ${ }^{32}$ This decalogue was drawn up because of the growing concern caused by the increasing use of the Internet by children, and because of a child's inadequate preparation when it comes to discriminating effectively among what is available.

In addition to the Internet, another of the technologies that is full of elements that might potentially threaten children's rights is video games. These, far from being a minority form of entertainment, are increasingly being played by more and more boys and girls. The contents of video games ${ }^{33}$ are in the main extremely violent, and foster racist and xenophobic attitudes. We do not yet know, however, to what extent such games can cause minors to internalise these attitudes and to accept them as their own. 


\section{A Proposal Concerning Children's Rights in the Age of Information and Communication Technologies.}

1 All children shall have the right to adequate nutrition and their mothers shall have the right to receive the necessary care to ensure their children are born healthy.

2 Children shall have the right to enjoy a rich affective environment in which suitably stable points of reference ensure a balanced emotional development.

3 All children shall have the right to live with those persons that fulfil the maternal and paternal roles but not as a synonym of a blood or legal bond, but as a synonym of love and understanding in harmonious coexistence.

4 Individual differences, as well as those differences that might be generated in each child as a result of the family or social education, must not be seen as the basis for denial of rights but as an argument for recognizing each person's distinctiveness.

5 All children shall have a space for learning and being educated in the family. (Policies must be implemented providing support for families and children).

6 All children should be given time to learn and play equivalent to a third of each day until the age of sixteen. (A watch needs to be kept on child labour and exploitation according to cultures and levels of schooling. Consider paying parents in order to send their sons, and in particular their daughters, to school.)

7 Children have the right to receive an education that enables them to appreciate the mass media and new technologies and that does not interfere with their ability to be critical and to transform the environment in which they live into one that is fairer and more equitable.

8 The freedom of conscience of each and every child should be respected.

9 Children have the right not to be used for promoting life styles or the purchase of goods and services contrary to or incompatible with a model of sustainable development that humanity establishes in order to widen and improve levels of justice, equality and dignity.

10 Children living in the various regions of the developed world have the right to enjoy a system of education that systematically avoids the formation of xenophobes. They should be trained in the use of dialogue and be given an appreciation of difference, and should not be taught to see inequality as a value.

11 An international agreement should guarantee that the policies of the world's governments, whether formally democratic or otherwise, are aimed at increasing social inclusion both locally and globally. Children have the right to participate in decision taking, to be involved and to exercise their control over the application, locally, regionally and globally, of the rights and duties that make up the framework of children's rights proposed here.

12 Children have their own rights, among which is that of being respected. Society, of which children form a part, has the duty through the passing of laws and other regulations to require other countries, institutions, companies and individuals not only to accept but also to promote their rights, including the right to be respected, while safeguarding their economic and legal viability. 


\section{Notes}

1. Castells (1997, 1998).

2. Giddens (1994, 1995).

3. Lenkow, L.; Tejero, E.; Torrabadella, L. (2000, p.14).

4. Cotarelo, R. (1992, p.42).

5. Autes, M. (2000, p.1).

6. López Hernández, G. (1999, p.43).

7. Brugué, Q.; Gomà, R.; Subirats, J. (2001, p.1).

8. Brugué, Q.; Gomà, R.; Subirats, J. (Op. cit. pp. 2-3).

9. Jolonch, A.(2002, p.45).

10. Study conducted by the International Institute of Labour Studies (ILLS).

11. Castel, R.(1991,p.139).

12. On 16 October 1996, the European Commission drafted the Green Paper on the protection of minors and human dignity in the new audio-visual and information services. Furthermore they have prepared additional laws that take a similar line, i.e. the protection of children in relation to the development of the Information and Communication Technologies.

13. Audio-visual technology includes television, video, computer games, mobile telephones, Internet, and other similar technologies.

14. In order to discover what young people think of the ICTs, how they use them and relate them to their future, various in-depth analyses of their expectations, wishes and aspirations, and how these technologies mediate their interpersonal relations with their peer group and with adults (parents, teachers, etc.) have been carried out. These include: Naval, C., Bringué, X y Sádaba, Ch. (2003); Amorós, P., Buxarrais, M.R. Casas, F. (2002). This last study analysed the impact on young people - boys and girls aged 12 to 16 - of the information and communication technologies (ICTs), identifying perceptions, values and varieties in their styles of communication. More specifically, the study sought to gain a more complete theoretical and applied knowledge of the life styles of young people in the current world of mass media, in order to increase our understanding of the impact of these media on learning and the social interaction of young people, and also of their rights and quality of life. The study was undertaken by three research groups, all of which are members of the interdisciplinary network of researchers examining children's issues Xarxa Catalana Interdisciplinar d'Investigadors/es sobre la Infancia (XCIII). They are GRISIJ (Grup de recerca sobre intervencions socioeducatives en la infancia i la juventut), the ERIDIQV (Equip de recerca sobre Infancia, Adolescència, Drets dels Infants i Qualitat de Vida) and the GREM (Grup de Recerca en Educació Moral).

15. When we speak of children's rights we are referring to the "Declaration on the Rights of the Child" passed by the General Assembly of the United Nations on 20 November 1959 ratified in the "Convention of the Rights of the Child" on 20 November 1989.

16. Cf. Area, M. (2001).

17. A study undertaken by the Centre d'Estudis Juridics de la Conselleria de Justicia de la Generalitat de Catalunya found that 20,825 Catalan girls and boys ( $2 \%$ of the child population) are victims of abuse due to negligence, or psychological, physical or sexual abuse.

18. When we speak of ICTs we refer specifically to screen technologies.

19. The research undertaken by Amorós, Buxarrais \& Casas (2002) is concerned with these issues.

20. The training programmes of infant, primary and secondary school teachers draws a distinction between two specialities: training in the use of the mass media and training in the use of ICTs. The former is understood as: teaching children to watch television and the latter: using the computer and the Internet in the school's activities. We would like to point out that many publications speak of New Technologies, but we prefer the term ICTs, since today they are no longer "new" technologies. 
21. The media of mass communication par excellence is the television.

22. The Second Asian Summit on children's rights and the mass media, held in Dhaka (Bangladesh) in March 2000, took a similar approach.

23. More than 2000 professional working in television participate and boys and girls are given the opportunity to explain their vision of the world.

24. Childwatch International Research Network is a network made up of research groups whose main objective is the study of children's rights. http://www.childwatch.uio.no/

25. CAC Consell de l'Audiovisual de Catalunya www.audiovisualcat.net

26. The Institute of Educational Sciences (ICE) at the University of Barcelona forms part of this Forum. We currently represent the ICE in this Forum.

27. The document Derechos de las personas usuarias de los medios audiovisuales was written as a guide for the agents that participate in television production, broadcasting and reception in order to further our understanding of the impact of television on viewers, as well as an attempt to promote an appropriate use of television. The charter of the "Rights of the users of audio-visual media" is based on the Universal Declaration of Human Rights which protects the rights of freedom of expression and information, of health and security, of access, of a linguistically and culturally plural society, the right to non-discrimination, the right to dignity, honour and privacy and the right to protect an individual's own image, rights that are also protected by the Spanish Constitution, the Statute of the Autonomy of Catalonia and Act 2/2000 drafted by the Catalan Audio-visual Council. The legislation contains many regulations that, directly or indirectly, refer to the rights of the users of the mass media. Guidelines have been drawn up in reference to the following rights: 1 . Right of Information. 2. Right to the protection of constitutional values 3. Right to the protection of children and adolescents. 4. Right to health and security 5. Right of access 6. Right to representation, consultation and participation 7. Right to training and education 8. Right of complaint.

28. The document Los valores en los contenidos de los programas televisivos dirigidos a la infancia $y$ la juventud was drawn up as a point of reference that could offer a series of recommendations and guidelines for producers and broadcasters with responsibility for making and selecting programmes for children and adolescents, as well as for parents and teachers who participate in the reception of television messages. The proposals it makes call on the various actors that intervene in the production, broadcasting and reception of television programmes to exercise their ethical responsibility. The recommendations made are grouped according to three types of value that it seeks to promote: 1) Values referring to the respect between peoples and social conflicts. 2) Values referring to the respect for the environment. 3) Values referring to personal identity.

29. The diptych: Televisión y familia: recomendaciones. This document offers recommendations to parents, other family members and child (under-12s) minders as to how to use the television properly. It is presented in the form of a decalogue. An audio-visual version is currently being prepared.

30. Journalists should never publish anything that might endanger children at risk. They should be particularly careful not to reveal any information that might undermine the dignity of a child, avoiding any mention of her name while telling her story so as to captivate the audience and generate interest.

31. Minors are exposed to various risks when they enter cyberspace: inappropriate contents (pornographic, racist, sects, materials related to drugs, deception and fraud), physical abuse (via chat rooms), harassment (via electronic mail, forums, chat rooms, etc), personal information (Javier Villate, 2001).

32. This document was published by the Human Rights Research Centre in Extremadura. On 6 February 2004 the International Safer Internet Day was held simultaneously in 15 countries (Australia, Bulgaria, Denmark, Germany, Greece, Hungary, Iceland, Ireland, Italy, Luxembourg, the Netherlands, Norway, Spain, Sweden and the United Kingdom). 
http://www.internetsegura.net/ The $e$-rights of boys and girls are: 1) the right to have access to information and technology, 2) right to freedom of expression and association, 3) right of boys and girls to be consulted and to give their opinion when introducing laws about the Internet that affect them, 4) right to be protected against exploitation, illegal trade, abuse and violence of any type that occur when using the Internet, 5) right to personal development and education and all opportunities that the new technologies such as the Internet can provide to improve their training, 6) right to the privacy of communications by electronic media, 7) right to relaxation, leisure, entertainment and play, 8) the fathers and mothers should have the right and the duty to orient, educate and to agree on a responsible use of the Internet with their sons and daughters, 9) the governments of the developed countries should undertake to co-operate with other countries in facilitating the Internet access of the latter and their citizens, and in particular that of their children, 10) right to benefit from the use of the new technologies in order to advance towards a world that enjoys greater health and greater solidarity, a world that is more peaceful, fairer, and more respectful of its environment, and one in which the rights of all children are respected.

33. The positive view of video games is given in Gros (1998).

\section{References}

Amorós, P., Buxarrais, M.R. y Casas, F. (2002). La influencia de las tecnologías de la información $y$ la comunicación en la vida de los chicos y chicas de 12 a 16 años. Barcelona: Institut d'Infancia i Mon Urbà. www.ciimu.org

Autes, M. (2000). Trois figures de la déliaison. En S. Karsz (dir). L'exclusion, définir pour en finir. Paris : Dunod.

Area, M. (coord.) (2001). Educar en la sociedad de la información. Bilbao: Desclée de Brouwer.

Brugué, Q.; Gomà, R. y Subirats, J. (2001). Exclusión Social. Barcelona: Universitat Autònoma de Barcelona.

Buxarrais, M.R. y Martínez, M. (1991). La Convención de 1989 y la educación moral. Revista Española de Pedagogia, no 190, 519-534.

Castel, R.(1991). De l'indigence à l'exclusión. La désafiliation. En J. Donzelot (coord.) Face a l'exclusion. Le modèle français. Paris : Esprit.

Castells, M. (1997). La Era de la Información. Vol. I La sociedad red. Madrid: Alianza Editorial.

Castells, M. (1998). Entender nuestro mundo. Revista de Occidente, no 205, 113-145.

The UNESCO Internacional Clearinghouse on Children and Violence (2000). www.nordicom.gu.se/unesco.html

Childwatch International Research Network. www.childwatch.uio.no The Catalan Interdisciplinary Research Network on Children's Rights and Children's Quality of Life. (XCIII)

Consell de l'Audiovisual de Catalunya, www.audiovisualcat.net

Cotarelo, R. (1992). Política social y racionalidad del mercado. En F. Alvarez-Uría (comp), Marginación e inserción. Los nuevos retos de las políticas sociales. Madrid : Endimión.

Giddens, A. (1994). Más allá de la izquierda y la derecha. El futuro de las políticas radicales. Madrid: Cátedra.

Giddens, A. (1995). Modernidad e identidad del yo. Barcelona: Ediciones Península.

Gros, B. (coord.) (1998). Jugando con videojuegos: educación y entretenimiento. Bibao:

Desclée de Brouwer.

Jolonch, A. (2002). Educació e infancia en risc. Barcelona: CETC-Portic.

Lenkow, L.; Tejero, E. y Torrabadella, L. (2000). Costos biogràfics en la lluita pel benestar.

Barcelona: Mediterrània. 
López Hernández, G. (1999). Condición marginal y conflicto social. Madrid: Talasa.

Martínez, M. (1998). El contrato moral del profesorado. Condiciones para una nueva escuela. Bilbao: Desclée de Brouwer.

Martínez, M. y Bujons, C. (coords.) (2001). Un lugar llamado escuela. En la sociedad de la información y de la diversidad. Barcelona: Ariel.

Micklewright, J. (2002). Social exclusión and children: an european view for a us debate. In Innocenti Working Papers, no 90, Florence: UNICEF.

Moncada, A. (2000). Manipulación mediática. Educar, informar y entretener. Barcelona: Ediciones Libertarias.

Naval, C., Bringué, X. y Sádaba, Ch. (2003). El impacto de las tecnologías de la información y la comunicación en las relaciones sociales de los navarros. Navarra: Comunidad Floral. 
160 Encounters/Encuentros/Rencontres 